Ethiopian Journal of Environmental Studies \& Management 9 (2): 179 - 196, 2016.

ISSN:1998-0507

doi: http://dx.doi.org/10.4314/ejesm.v9i2.6

Submitted: November 13, 2015

Accepted: March 07, 2016

\title{
ASSESSMENT OF VEHICLE INSPECTION SERVICES IN IJEBU ZONE OF OGUN STATE, NIGERIA
}

\author{
RAJI, B.A. \\ Department of Geography and Regional Planning, Olabisi Onabanjo University Ago-Iwoye, \\ Ogun State, Nigeria \\ Email: rajbasholaniyi@yahoo.co.uk
}

\begin{abstract}
This study examines vehicle inspection services (VIS) and motorists' perceptions of VIS activities as well as motorists' vehicles condition in ljebu zone of Ogun State Nigeria. Thirty vehicle inspection officers (VIOs) were purposively interviewed on the basis of number of staff in three VIS stations and 599 structured questionnaires were randomly administered to motorists based on proportion allocation of sample size to wards in selected garages of local government areas of the zone. Descriptive and inferential statistics were used for the analyses. From January 2014 to August 2015, 15,886 vehicles were inspected for roadworthiness (RW) of which $73.6 \%$ passed and $26.4 \%$ failed the test. In Abigi station $56.8 \%$ vehicles inspected failed the test, whereas $61.5 \%$ and $78.8 \%$ vehicles inspected inljebu - Igbo and ljebu - Ode stations respectively passed the test. The total number of vehicles that passed $(\bar{x}=1104.7500)$ the test in the zone is positively higher than vehicles that failed $(\bar{x}=287.3750)$ and significant at $(t=12.32, p \leq 0.05)$.Despite $87.8 \%$ motorists' vehicles are imported but used and $12.2 \%$ are new, the conditions of the vehicles based on the study assessment are more of good condition than being bad condition and significant at $\left(X^{2}=16.92, p \leq 0.05\right)$. However, $83.4 \%$ of the causes of road accidents in the zone are credited to man. Despite the challenges of the VIOs and dissatisfaction on their performance by $69.6 \%$ of motorists, most of the VIOs (63.3\%) are satisfied with the job. Therefore, it is recommended that intended and existing motorists should visit VIS stations for driving and routine $R W$ tests respectively, provide periodic safety and roadworthiness enlightenment to motorists, equip VIS stations with state of the art equipment and patrol vehicles, organize regular training for staff and maintain periodic staff remunerations review so as to help in achieving successful and sustainable safety of life and properties on Nigeria roads.
\end{abstract}

Key Words: VIS, VIOs, Motorists, Ijebu Zone, Ogun State, Nigeria.

\section{Introduction}

As road transport system is responsible for development, of all modes of transport, it is the most dangerous and costly in terms of human lives (Raji and Solanke, 2013; Raji, 2014). This is because of various negative externalities such as traffic congestion, environmental pollution and especially road traffic accidents which are regarded as unforeseen and often disastrous events usually producing unexpected and unpleasant consequences 
to lives and properties (Onakomaiya, 1991a; 1991b; Olokesusi and Asiyanbola, 1997; Raji, 1998; Dabiri, 2006). European Transport Safety Council (1999) observed that road transport represent $90 \%$ of accident fatalities in many countries. EUROPA (2003) equally termed road transport as the most dangerous and the most costly in terms of human lives. Although, Filibus (2012) perceived that road transport sub- sector is the dominant mode for movement of goods and services and it accounts for $99 \%$ of all domestic freight and passenger movement in Nigeria. However, it has been observed that despite the importance of road transport, the problem of road traffic accident in Nigeria is such that hardly does a day pass by without a record of an accident on highways. Hence, economic cost of traffic accidents in Nigeria was estimated at1.9 billion Naira (9.5 million USD) (Arosanyin, 2002; Okoko and Arosanyin, 2004; Raji, 2014).

In Nigeria, the gradual neglect of other modes of transport has made road transport a principal mode and it is increasingly associated with the rise in road accident and premature deaths, as well as physical and psychological handicaps in Nigeria. Apart from the loss of lives, road traffic injuries have implication on health, social and economic life, property damage, administration cost and travel delay (Raji and Solanke, 2009; Raji, 2014; Badejo, 2014a).

Road accidents in terms of frequency of occurrence and losses in Nigeria are seen to supersede accidents from other modes (Badejo, 2012; 2014b).Nonetheless, Rajiet al. (2014) noted that the anti-thesis to road traffic accident is propagation of 'road traffic safety' which is concerned with adequate observation of necessary precautions against bodily injury caused by road traffic accidents, either by preventing its occurrence or by mitigating its effects. In response to reduction in road transport externalities, the government set up various agencies at Federal and State level of which include Federal Road Safety Commission (FRSC), Vehicle Inspection Services (VIS), Traffic Wardens of the police force, and National Emergency Management Agencies (NEMA).

Otuyemi (2006), Filibus (2012), Alade (2012), Raji (2014) and Lagos State Ministry of Transportation (2015)observed that in spite of all institutional frameworks put in place by government, the spate of road traffic accident occurrence in the country due to unworthiness of most of the vehicles involved is increasingly worrisome. Therefore, of all the government agencies in charge of road safety in the country, the agency in charge roadworthiness (RW) certification of automobiles is VIS of various states in Nigeria.

Roadworthiness testing according to Reinhard (2005) is seen as one of the best ways to improve road safety in developing cities. Thus, the principal responsibilities of VIS through Vehicle Inspection Officers (VIOs) are to enforce and administer traffic laws and regulations in order to ensure the safety of lives and properties on Nigerian roads. So, the basic duties of VIS include (i) inspection and issuance of roadworthiness certificate to vehicles, (ii) maintaining sanity on roads and highways with routine check of vehicles for RW through physical observation, (iii) training and testing drivers for driver's license, (iv) organizing seminar and public lectures on road safety, (v) carrying out inspection on accident vehicles and (vi) certification of driving schools (Filibus, 2012; Alade, 2012; Lagos State Government, 2013).

Alade (2012) study on VIS roles across Nigerian states showed that focus is more on revenue generation to the detriment of 
Safety, neglect of the VIS operations, none establishment of effective motor vehicle administration agency for effective performance. Filibus (2012) research also showed deficiencies in the areas of staffing, equipment acquisition and low budgetary provision. However, Daniel (2015) observation of dissolution of VIS by Kaduna State government stems from over employment of assisting VIOs, wide range of indiscipline and misconducts and alleged extortion from the public. The varied observations of the studies about VIS activities and the frequent road accidents occurrence on Ogun state roads, most of which are attributed to unworthiness of the vehicles necessitated this study. Thus, the research aims at assessing the services of VIS by examining VIOs activities, engages motorists' on activities of VIS and as well observed the bad or good state of vehicles of motorists in Ijebu Zone of Ogun state. This is with the view of appraising VIS performance and also suggests measures at improving VIS activities so as to ensure sustainable safety of lives and properties on Ogun state roads.

\section{Study Area}

The study area is Ijebu zone of Ogun state. Ogun State is one of the thirty six (36) states in Nigeria. It is located in south western Nigeria and lies in latitudes $6^{\circ}$ $29^{\prime} \mathrm{N}$ and $7^{\circ} 55^{\prime} \mathrm{N}$ and longitudes $2^{\circ} 43^{\prime} \mathrm{E}$ and $4^{\circ} 31^{\prime} \mathrm{E}$ (figure 1). The state is bounded in the west by the Republic of Benin, east by Ondo State, and north by Oyo state. Lagos State and the Atlantic Ocean are to the south of the state. The state covers about 16,762square kilometer which is approximately 1.81 percent of Nigeria's land mass of about 923,768 square kilometers.

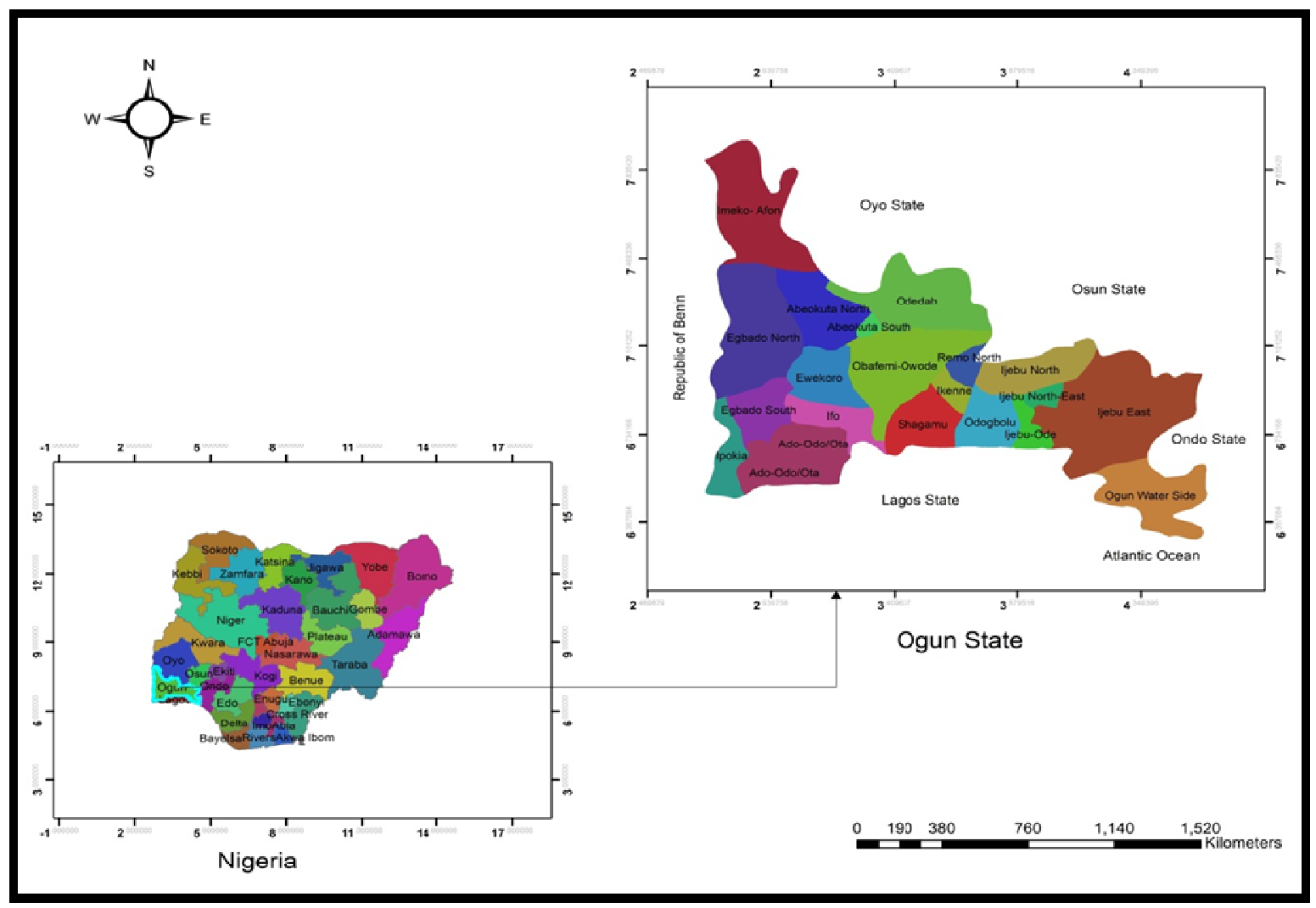

Figure1: Nigeria and Ogun Sate Maps 
Ijebu Zone is one is one of the four geo-political divisions of Ogun State that was carved out of the defunct western state of Nigeria on February $3^{\text {rd }} 1976$. The zone comprises of six local government areas of the state (figure 2) and lies within the tropics. It is bounded in the west by Remo Zone which comprises of Sagamu, Ikenne and Remo North local government areas, in the east by Ondo state, in the north by Oyo and Osun States and in the south by Lagos State and the Atlantic Ocean. The choice of the Ijebu Zone over other zones in the state is attributed to: (i) increase in vehicular activities due to road network such as Sagamu - Benin Expressway, Ijebu - Ode - Ibadan road and other roads linking the zone with important towns in south western and Eastern Nigeria such as Ibadan, Akure, Benin, Enugu and Port Harcourt (ii) availability and accessibility of vehicles roadworthiness records in the stations in the zone.

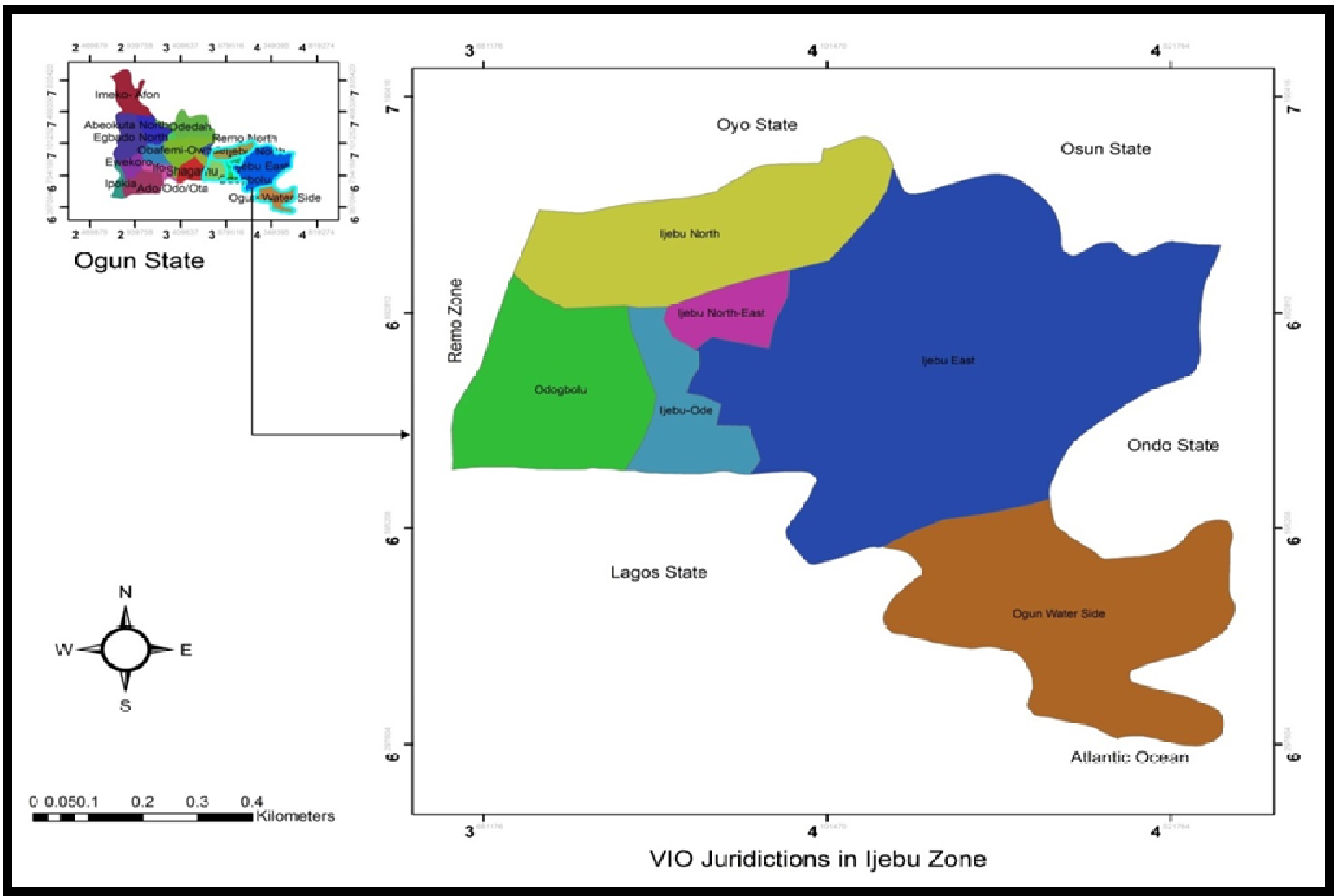

Figure 2: Map of VIO Jurisdictions in Ijebu Zone

The six local government areas in the study area which include Ogun Water Side, Ijebu North, Ijebu Ode, Ijebu East, Ijebu North East and Odogbolu encompass rural and urban centres in the state. Economic activities thrive in rural and urban centres of the zone. Among these economic activities are varieties of farm product, public primary schools, technical college, registered private nursery and primary schools, 1 college of education, 1 polytechnic, 2 public universities and 2 private universities. Also, there are hospitals/clinics (public and private), maternity centres, dispensaries, comprehensive/primary health centres and a dental centre. More so, extensive trading, commercial enterprises, light and 
heavy industrial organization are found in different urban centres of the zone. People in the zone also engaged in paid employment of the local, state and federal government agencies, others engage in business activities which are dominated by distributive trade, personal services, transportation, finance and insurance services.

Rural and urban activities are noticeable in the zone. Also, noticeable is tourist attraction such as Birikisu Sungbo Shrine which increases transportation services with the slogan 'safe arrival to various destinations'.

\section{Methods}

This study is based on the services of VIS in Ogun State. Data of inspected vehicles were collected from the zonal headquarter in Ijebu - Ode. Activities of VIS and perceptions of VIS activities were obtained from VIOs and motorist respectively using two (2) different sets of structured questionnaires. Observations were also based on physical assessment of operational facilities, available equipment at VIS stations and state of vehicles of motorists sampled. Of the twenty Local Government Areas of the state, VIS offices are situated in eleven local (11) government areas but has twelve (12) stations (table 1).

Table1: Zones, Local Government Area and Headquarters and VIO Stations in Ogun State

\begin{tabular}{lllll}
\hline S/No & zones & Local Government Area & Headquarters & VIO Stations \\
\hline 1 & & Ogun Water Side & Abigi & \\
2 & & Ijebu North & Ijebu Igbo & \\
3 & & Ijebu Ode & Ijebu Ode & Abigi \\
4 & Ijebu & Ijebu East & Ogbere & Ijebu Igbo \\
5 & & Ijebu North East & Atan & Ijebu Ode \\
6 & & Odogbolu & Odogbolu & \\
7 & & Sagamu & Sagamu & \\
8 & Remo & Ikenne & Ikenne & Sagamu \\
9 & & Remo North & Ishara & \\
10 & & Ifo & Ifo & Ojodu Abiodun \\
11 & & Ipokia & Idi Iroko & Idi Iroko \\
12 & & Yewa North & Ayetoro & Ayetoro \\
13 & Yewa & Yewa South & Ilaro & Ilaro \\
14 & & Imeko Afon & Imeko & Sango \\
15 & & Ado Odo/Ota & Ota & Agbara \\
16 & & Abeokuta North & Ibara & \\
17 & & Abeokuta South & Ake & \\
18 & Egba & Odeda & Kotopo & Ibara \\
19 & & Obafemi Owode & Obafemi Owode & Kotopo \\
20 & & Ewekoro & Ewekoro & \\
\hline
\end{tabular}

The study was conducted on 30 VIOs and 599 motorists. In traffic survey, one hundred (100) interactive situations with motorists are permissible at a cordon point in the literature (Varhelyi, 1998; Raji et al.,
2014). Therefore, an interaction with 100 motorists in each of the local government areas under Ijebu zone at their major garages provided anticipatory six hundred (600) questionnaires to be administered. 
But based on proportionate allocation to wards in each local government (table 2), five hundred and ninety-nine (599) questionnaires were distributed by twenty four (24) field assistants. A pilot study to the offices of the VIOs revealed that the average staff strength of the VIOs in each of the station ranges from eight to nine and they comprise of scaled (professional) and un-scaled (assisting) staff. In the administration of the questionnaires to the staff of (VIS), about thirty (30) VIOs were interviewed (table 2).

Table 2: Allocation of distributed questionnaires in Ijebu Zone of VIS

\begin{tabular}{|c|c|c|c|c|c|c|c|}
\hline $\mathrm{S} / \mathrm{No}$ & zone & $\begin{array}{l}\text { Local } \\
\text { Government } \\
\text { Area }\end{array}$ & Headquarters & Wards & $\begin{array}{c}\text { Ward } \\
\text { Proportion }\end{array}$ & $\begin{array}{c}\text { Number of } \\
\text { Motorists } \\
\text { Sampled }\end{array}$ & $\begin{array}{l}\text { Number of } \\
\text { VIOs } \\
\text { Sampled }\end{array}$ \\
\hline 1 & & $\begin{array}{l}\text { Ogun Water } \\
\text { Side }\end{array}$ & Abigi & 10 & 0.1471 & 88 & 8 \\
\hline 2 & & Ijebu North & Ijebu Igbo & 11 & 0.1618 & 97 & 10 \\
\hline 3 & Ijebu & Ijebu Ode & Ijebu Ode & 11 & 0.1618 & 97 & 12 \\
\hline 4 & & Ijebu East & Ogbere & 11 & 0.1618 & 97 & None \\
\hline 5 & & $\begin{array}{l}\text { Ijebu North } \\
\text { East }\end{array}$ & Atan & 10 & 0.1471 & 88 & None \\
\hline $\begin{array}{l}6 \\
\text { Total }\end{array}$ & & Odogbolu & Odogbolu & $\begin{array}{l}15 \\
68\end{array}$ & 0.2206 & $\begin{array}{l}132 \\
599\end{array}$ & $\begin{array}{c}\text { None } \\
30\end{array}$ \\
\hline
\end{tabular}

Data obtained were analyzed using IBM SPSS Statistics 20 software. The software was used to run Analysis of Variance (ANOVA) on inspected monthly vehicles that passed and failed RW test in the zone. Also, $t$ - statistics was used to test for the significant difference in the means total of vehicle that passed and failed RW test and Chi - Square $\left(\mathrm{X}^{2}\right)$ was used to test for the significant difference in the conditions of motorists' vehicles. Results of data obtained from VIS and motorists are discussed in section four.

\section{Results and Discussion}

\section{Characteristics of Participants}

Regarding the VIOs, $10 \%$ are females and $90 \%$ are males whose age range from 20 years to \pm 50 years. $96.7 \%$ are married and $3.3 \%$ are single with $73.3 \%$ attaining post-secondary education and $26.3 \%$ attaining secondary education. The motorists comprise of $27.5 \%$ of females and $72.5 \%$ males whose age range is similar to the VIOs.64\% of the motorists are married and $36 \%$ are ether single, divorced or widowed. Also, 26\% are below primary education, $36 \%$ are of secondary education and $42 \%$ have post-secondary education. From the analyses, there are more male participants among VIOs and motorists than female. In case of the VIOs, our pilot study clearly showed that there are more male VIOs than female and the female VIOs are more saddled with administrative responsibilities than technical responsibilities. Although, there are more male respondents among the motorists, the variance does not signify that there are more male motorists than female but indicate those respondents randomly selected in the course of questionnaire distribution. In area of educational qualification almost all the participants acquire formal education which seems sufficient in their ability to interpret the questionnaire. 
Vehicle Inspection Service Activities and Perceptions and State Motorists Vehicles Vehicle Inspection Service Activities

Vehicle Inspection Officers (VIOs) are saddled with responsibilities within and outside their testing stations. Some of the duties performed by the VIOs in the study are grouped into (i) Vehicle Inspection, (ii) Driving Test (iii) Accident Inspection and Revenue Generation and (iv) Challenges Facing VIOs.

\section{Vehicle Inspection}

Vehicle inspection is carried out on vehicles to ascertain their RW, after which vehicles that passed the test are issued roadworthiness certificate. Statutorily, every vehicle is expected to visit testing ground once in every six months. In the course of study, records of vehicles visited the three stations in the zone from January 2014 to August 2015 are summarized in table 3a. Table 3ashows the number of vehicles and motorcycles that passed and failed RW test in Abigi, Ijebu - Igbo and Ijebu - Ode stations of the VIS. Buses, Pickups, trucks and cars inspected are classified motor vehicle (MV) and motorcycles and tricycles are classified motorcycle (MC). Motor vehicle and motorcycle that passed or failed the test are represented by letters (P) and (F) respectively.

Of the $420 \mathrm{MV}$ that took RW test in Abigi station, $42.9 \%$ passed the test and high proportion of the MV (57.1\%) failed the test. Similarly, of 163 MC tested, high proportion of the MC $(57.1 \%)$ failed the test (table 3b). In Ijebu - Igbo station, while majority of the MV (67.8\%) passed the test, the proportion of $\mathrm{MC}$ that failed the test $(75.6 \%)$ is high. However, in Ijebu - Ode station high proportion of MV (82.6\%) and MC (67.1\%) passed RW test. Row 9 of table $3 \mathrm{~b}$ also described the total number of vehicle that passed and failed the RW test irrespective of types of vehicles involved. From the results, high proportion of vehicle in Abigi station (56.8\%) failed the test. Unlike Abigi station, high proportion of vehicle that took RW test in Ijebu - Igbo (61.5\%) and Ijebu - Ode (78.8\%) passed the test. 
Table 3a: Monthly number of motor vehicle and motorcycle that passed and failed roadworthiness test in Ijebu zone of VIS

\begin{tabular}{|c|c|c|c|c|c|c|c|c|c|c|c|c|c|c|c|c|c|c|}
\hline \multirow{3}{*}{ Aug.'15 } & \multicolumn{6}{|c|}{ ABIGI } & \multicolumn{6}{|c|}{ IJEBU - IGBO } & \multicolumn{6}{|c|}{ IJEBU - ODE } \\
\hline & \multicolumn{2}{|c|}{$\begin{array}{c}\text { Motor } \\
\text { Vehicle }\end{array}$} & \multicolumn{2}{|c|}{$\begin{array}{l}\text { Motor } \\
\text { Cycles }\end{array}$} & \multicolumn{2}{|c|}{ Total } & \multicolumn{2}{|c|}{$\begin{array}{c}\text { Motor } \\
\text { Vehicle }\end{array}$} & \multicolumn{2}{|c|}{$\begin{array}{l}\text { Motor } \\
\text { Cycles }\end{array}$} & \multicolumn{2}{|c|}{ Total } & \multicolumn{2}{|c|}{$\begin{array}{l}\text { Motor } \\
\text { Vehicle }\end{array}$} & \multicolumn{2}{|c|}{$\begin{array}{l}\text { Motor } \\
\text { Cycles }\end{array}$} & \multicolumn{2}{|c|}{ Total } \\
\hline & $\mathrm{P}$ & $\mathrm{F}$ & $\mathrm{P}$ & $\mathrm{F}$ & $\mathrm{P}$ & $\mathrm{F}$ & $\mathrm{P}$ & $\mathrm{F}$ & $\mathrm{P}$ & $\mathrm{F}$ & $\mathrm{P}$ & $\mathrm{F}$ & $\mathrm{P}$ & $\mathrm{F}$ & $\mathrm{P}$ & $\mathrm{F}$ & $\mathrm{P}$ & $\mathrm{F}$ \\
\hline Jan & 4 & 7 & 3 & 3 & 7 & 10 & 11 & 9 & 4 & 1 & 15 & 10 & 33 & 23 & 63 & 26 & 96 & 49 \\
\hline Feb & 6 & 9 & 1 & 2 & 7 & 11 & 4 & 5 & 4 & 2 & 8 & 7 & 20 & 19 & 41 & 23 & 61 & 42 \\
\hline Mar & 6 & 6 & 3 & 2 & 9 & 8 & 9 & 8 & 7 & - & 16 & 8 & 66 & 22 & 61 & 29 & 127 & 51 \\
\hline April & 3 & 5 & 2 & 3 & 5 & 8 & 8 & 8 & 9 & 2 & 17 & 10 & 38 & 12 & 54 & 40 & 92 & 52 \\
\hline May & 5 & 7 & 2 & 4 & 7 & 11 & 8 & 5 & 6 & 1 & 14 & 6 & 42 & 10 & 76 & 30 & 118 & 40 \\
\hline June & 7 & 5 & 3 & 3 & 10 & 8 & 7 & 3 & 4 & 2 & 11 & 5 & 60 & 22 & 62 & 61 & 122 & 83 \\
\hline July & 6 & 8 & 1 & 2 & 7 & 10 & 9 & 4 & 8 & 2 & 17 & 6 & 55 & 22 & 83 & 49 & 138 & 71 \\
\hline Aug & 3 & 3 & 1 & 2 & 4 & 5 & 8 & 1 & 7 & 5 & 15 & 6 & 45 & 15 & 97 & 67 & 142 & 82 \\
\hline Sep & 5 & 2 & - & - & 5 & 2 & 9 & 5 & 7 & 3 & 16 & 8 & 40 & 19 & 84 & 29 & 124 & 48 \\
\hline Oct & 6 & 8 & - & 2 & 6 & 10 & 11 & 3 & 5 & 5 & 16 & 8 & 48 & 28 & 43 & 21 & 91 & 49 \\
\hline Nov & 8 & 7 & 1 & 1 & 9 & 8 & 8 & 6 & 6 & 5 & 14 & 11 & 41 & 12 & 44 & 28 & 85 & 40 \\
\hline Dec & 6 & 9 & 3 & 1 & 9 & 10 & 6 & 8 & 9 & 1 & 15 & 9 & 36 & 15 & 32 & 23 & 68 & 38 \\
\hline Jan & 26 & 30 & 10 & 12 & 36 & 42 & 232 & 142 & 29 & 44 & 261 & 186 & 930 & 323 & 180 & 105 & 1110 & 428 \\
\hline $\mathrm{Feb}$ & 10 & 17 & 5 & 9 & 15 & 26 & 237 & 11 & 15 & 31 & 252 & 42 & 753 & 129 & 150 & 66 & 903 & 195 \\
\hline Mar & 9 & 12 & 3 & 4 & 12 & 16 & 196 & 96 & 17 & 40 & 213 & 136 & 710 & 239 & 146 & 63 & 856 & 302 \\
\hline April & 9 & 11 & 2 & 3 & 11 & 14 & 245 & 106 & 10 & 29 & 255 & 135 & 796 & 120 & 123 & 78 & 919 & 198 \\
\hline May & 10 & 15 & 8 & 10 & 18 & 25 & 182 & 85 & 21 & 45 & 203 & 130 & 738 & 58 & 101 & 50 & 839 & 108 \\
\hline June & 10 & 15 & 8 & 10 & 18 & 25 & 182 & 85 & 21 & 45 & 203 & 130 & 820 & 85 & 120 & 60 & 940 & 145 \\
\hline July & 20 & 30 & 7 & 10 & 27 & 40 & 295 & 171 & 60 & 110 & 355 & 281 & 898 & 302 & 160 & 29 & 1058 & 331 \\
\hline Aug & 23 & 32 & 7 & 10 & 30 & 42 & 265 & 156 & 47 & 105 & 312 & 261 & 1137 & 68 & 180 & 54 & 1317 & 122 \\
\hline TOTAL & 182 & 238 & 70 & 93 & 252 & 331 & 1932 & 917 & 296 & 478 & 2228 & 1395 & 7306 & 1543 & 1900 & 931 & 9206 & 2474 \\
\hline
\end{tabular}


Table 3b: Number of MV, MC that passed and failed RW test

\begin{tabular}{lllll}
\hline Stations & Motor Vehicle & \multicolumn{3}{l}{ Motor Cycle } \\
\hline & Passed & Failed & Passed & Failed \\
Abigi & $\mathrm{N}=420$ & & $\mathrm{~N}=163$ & \\
& $180(42.9)$ & $238(57.1)$ & $70(42.9)$ & $93(57.1)$ \\
Ijebu - Igbo & $\mathrm{N}=2849$ & & $\mathrm{~N}=1213$ & \\
& $1932(67.8)$ & $917(32.2)$ & $296(24.4)$ & $478(75.6)$ \\
Ijebu - Ode & $\mathrm{N}=8849$ & & $\mathrm{~N}=2831$ & \\
& $7306(82.6)$ & $1543(17.4)$ & $1900(67.1)$ & $931(32.9)$ \\
& Total Number of Vehicles & & \\
Abigi & Passed & Failed & Total & \\
Ijebu - Igbo & $252(43.2)$ & $331(56.8)$ & 583 & \\
Ijebu - Ode & 2228(61.5) & $1395(38.5)$ & 3623 & \\
\hline
\end{tabular}

Since inspection of vehicle is key to VIS and the society at large an ANOVA test was carried out to test if there is no significant variations in the means of (i) total vehicle inspected (ii) total vehicles passed, and (iii) total vehicles that failed the RW test in the three stations of the zone. Results of the analysis of variance are presented in table $3 \mathrm{c}$.

Table 3c: Variations and differences in monthly average number of vehicles that passed and failed RW test

Analysis of Variance

\begin{tabular}{lll}
\hline Stations & Monthly Mean & F-Ratio \\
\hline & Total Vehicle & \\
Abigi & 29.15 & $14.758^{* *}$ \\
Ijebu - Igbo & 181.15 & \\
Ijebu - Ode & 584 & \\
& Passed Vehicle & $8.169^{* *}$ \\
Abigi & 12.6 & \\
Ijebu - Igbo & 111.4 & \\
Ijebu - Ode & 460.3 & $14.185^{* *}$ \\
& Failed Vehicle \\
Abigi & 16.55 & \\
Ijebu - Igbo & 69.75 & $\mathrm{t}$ \\
Ijebu - Ode & 123.7 & \\
Paired Sample t - test & & $12.32^{* *}$ \\
Variables & Mean & \\
Jan-Aug 2014-2015Passed & 1104.7500 & \\
Jan-Aug 2014-2015Failed & 287.3750 & \\
\hline$* *$ significant at 5\% & &
\end{tabular}

Table $3 \mathrm{c}$ shows significant variations at $5 \%$ in the total number of vehicle inspected $\left(F_{57}^{2}=14.758\right)$, the total number of vehicles that passed $\left(F_{57}^{2}=8.169\right)$ and the total number of vehicles that failed $\left(F_{\mathrm{5} 7}^{2}=14.185\right)$ monthly inspection test in the three stations. The significant variations observed in the results of the analyses (table 3c) are shown clearly 
in pictorial presentation (figure 3) of average values of the total vehicles, number of vehicles that passed and failed RW test. Though, there are significant variations in the average values

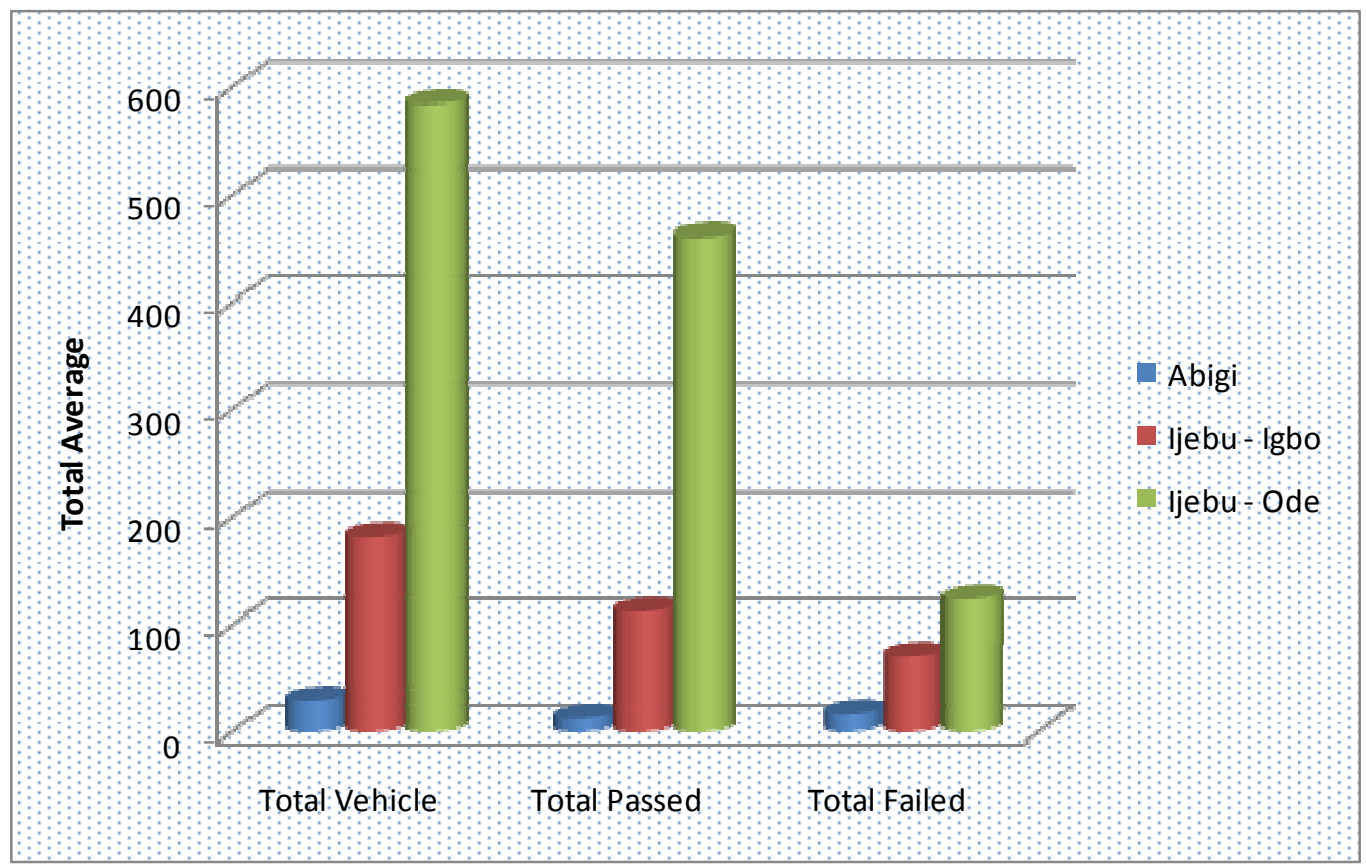

Figure 3: Monthly average of vehicles involved in RW test

of number of vehicles, number passed and failed RW test, there is the need to test for the significant difference total vehicles that passed and failed the test. Row 15 of table $3 \mathrm{c}$ further described the significant difference that exists between the mean value of vehicles that passed and failed the RW test conducted by the VIOs from January to August 2014 and January to August 2015 respectively. The result from the analysis shows a significant difference $(t=12.32, p<0.05)$ in the mean total number of vehicles that passed and failed RW test in the zone. The result of the ttest, affirm that the mean value of vehicles that passed RW test $(\bar{x}=1104.7500)$ is positively higher than the mean value of vehicles that failed $(\bar{x}=287.3750)$ the test in the zone.

\section{Driving Test}

Driving test is another responsibility VIS also conducts to would be drivers.
These tests involve practical and theoretical applications. The study revealed that less than twenty (20) persons came for driving tests in each of the stations on monthly basis. The officers interviewed were of the opinion that the number of people that came for monthly driving tests are low (figure 4) because many of the motorists' often obtain license without being tested and certify to drive. According to VIOs interviewed, their experience during patrol had shown that most mishaps observed along their routes are sometimes caused by naivety of the motorists. They further observed that going through driving test could have exposed motorists to road signs and some technicalities required when driving, such that experience gained would have gone a long way in assisting drivers to take necessary precaution towards reducing road mishaps. 
Accident Inspection and Revenue Generation

Vehicle inspection officers are also responsible for the inspection of vehicles that are involved in accident. The inspection is to ascertain the causes of the accident in order to assist the police in their investigation. Besides, the release of any vehicle from the police station after mishaps or other related offences required the certification of the VIOs. The study as shown in table 4 revealed that a high proportion of the VIOs (83.4\%) were of the opinion that man is one of the causative factors of the mishaps in the zone. Also, $13.3 \%$ and $3.3 \%$ of the VIOs stated that mechanical and environmental factors respectively are also part of the causes of mishaps. They further observed that mechanical causes of mishaps are often induced by man and these include over speeding, drunk driving, inexperience, use of phone on wheel, neglect and so on. In the case of neglect, the vehicle may have been displaying signs of mechanical imbalance relating to braking system of the vehicle which the driver may insist on managing the vehicle to its destination. The survey revealed that the braking scenario sometimes result into road traffic accident when the driver finds it difficult to control the vehicle.

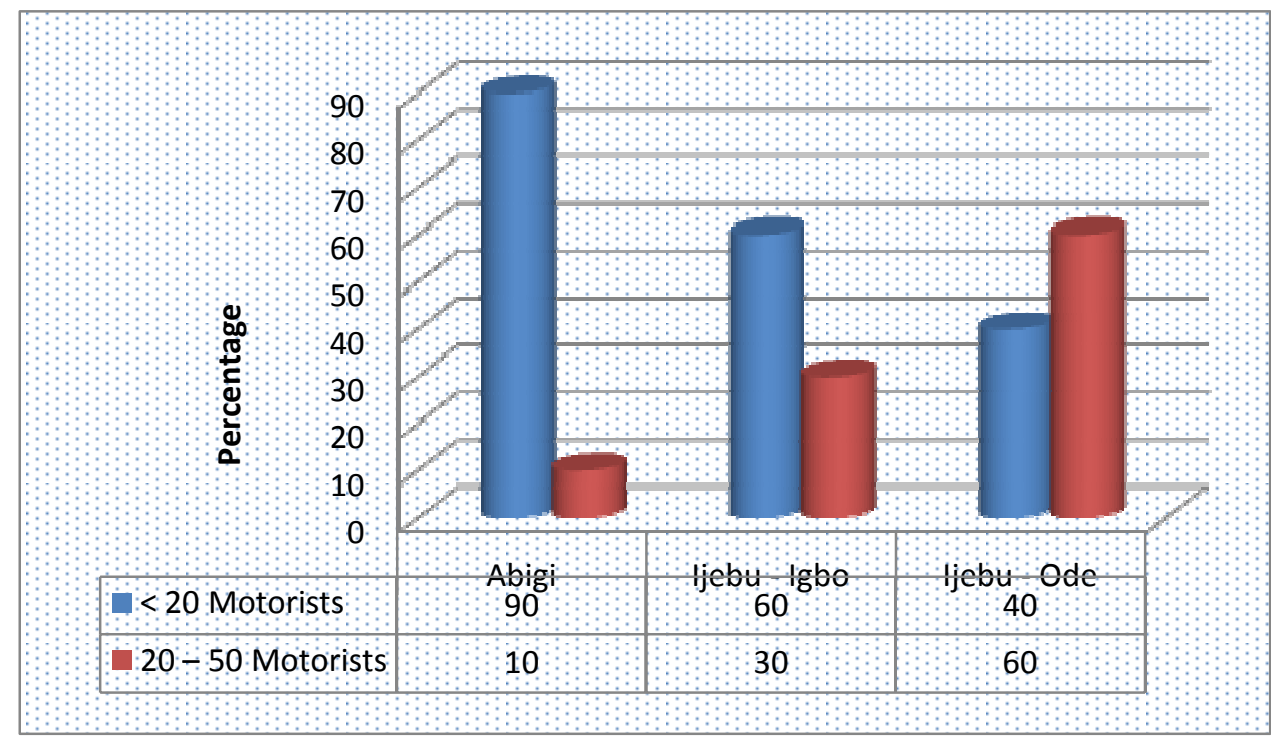

Figure 4: Monthly Percentage of Average Motorists that call for RW test in Ijebu Zone

Table 4: Causes of road traffic accidents and average monthly revenue generation of VIS in the zone.

\begin{tabular}{ll}
\hline Variables & Frequency (\%) \\
\hline Accident Causation Factors & $25(83.4)$ \\
Human & $4(13.3)$ \\
Mechanical & $1(3.3)$ \\
Environmental & \\
Average Monthly Revenue Generation & - \\
$< \pm 50,000$ & - \\
$\# 50,000-\$ 150,000$ & $26(86.7)$ \\
$\# 151,000-\$ 250,00$ & $4(13.3)$ \\
\hline 250,00 &
\end{tabular}


The study also showed that VIOs move out on daily basis within the zone in order to enforce traffic laws by impounding vehicles that the driver has no drivers' license, RW certificate, and insurance. Motorists arrested are fined and compel to obtain RW certificate before securing the release of their vehicles. Apart from levies generated from RW certificate, fines gained during patrol are also source of revenue generation for government. Therefore, average monthly revenue generated from issuance or renewal of RW certificates, accident inspection fees and fines paid into government purse (table 4)

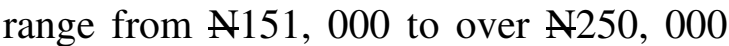
which is equivalent to $(\$ 1,276)$. In spite of revenue generation capacity of the VIS to the, the agency is burdened with multitudes of problems that are discussed in the subsequent section.

\section{Challenges Facing the VIOs}

The significance of the activities VIS through VIOs in the zone and the state cannot be over emphasized. However, the traffic officers are faced with multitudes of problems ranging from poor remunerations, lack of regular staff training and inadequate equipment to mention but a few. The study revealed that despite high percentage administrative compliment $(73.3 \%)$, high percentages of the VIOs interviewed were of the opinion that they were not professionally $73.3 \%$ ) and technically $(98.7 \%)$ equipped (table 5). Though, $63.3 \%$ of the VIOs are satisfy with their job, nevertheless, 100\%, 80\% and $60 \%$ of the VIOs were of the opinion that regular staff training and road safety campaign is elusive, being poorly remunerated and lack vehicle for routine patrol respectively. More so, the officers sampled were of the opinion that the state government is more interested on revenue generation from the three stations than investing on equipment, training of officers and increasing officers' remunerations.

Table 5: Some of the challenges facing VIOs in Ijebu zone

\begin{tabular}{ll}
\hline Variables & Frequency $(\%)$ \\
\hline Professionally Equipped & $8(26.7)$ \\
Yes & $22(73.3)$ \\
No & \\
Technically Equipped & $4(1.3)$ \\
Yes & $26(98.7)$ \\
No & \\
Administratively Equipped & $22(73.3)$ \\
Yes & $8(26.7)$ \\
No & \\
Regular Staff Training and Road Safety Campaign & - \\
Yes & $30(100)$ \\
No & \\
Job Satisfaction & $19(63.3)$ \\
Yes & $11(36.7)$ \\
No & \\
Poor Remuneration & $24(80)$ \\
Yes & $6(20)$ \\
No & \\
Availability of Patrol Vehicle & $18(60)$ \\
Yes & $12(40)$ \\
No &
\end{tabular}


The research further showed that in spite of the effort of VIS in making sure of that vehicles on the state roads are roadworthy, neglect by the government and aforementioned challenges make it very difficult for the agency to: (i) function effectively (ii) reduce rate of road traffic accidents, (iii) safe the life of both rich and poor from bad drivers (iv) encourage young school leavers to take VIS job. Section 4.2.2 further examines the activities of VIS through motorists' perceptions and as well discusses the condition of motorists' vehicles.

\section{Perceptions and State of Motorists Vehicles}

The results in table 6 show that all the motorists $(100 \%)$ indicated that they do have contact with the VIS. The results also showed that high proportion of the motorists $(78.6 \%)$ contact with VIS is to obtain roadworthiness certificate while the proportion of motorists that has contact with VIS when obtaining drivers' license and carry out frequent vehicle check for roadworthiness represent $10.7 \%$ each. In driver license acquisition, percentage of motorists that acquires drivers' license through VIS (10.7\%) is lower than FRSC
(70.3\%) and driving school (13\%). Lower percentage observation of the motorist's driver license acquisition through VIS confirms submission of the VIOs on low number of motorists that do turn up for driving test (figure 4). The result can also be attributed to earlier observation of lower proportion of motorists contact type (table 6) with VIS. Regarding thoroughness of VIS on RW, high proportion of the motorists $(72 \%)$ rated VIS low. Nevertheless, the proportion of motorists believing that VIS has positive impact on RW (65.8\%) is higher than negative rating $(34.2 \%)$. In terms of road safety and publicity campaign, high proportion of the motorists $(67.1 \%)$ believes that the publicity of VIS on road safety is poor. Despite the positive role of VIS on road safety activities, poor publicity observed by motorists may have contributed to apparent dissatisfaction in VIS performance on RW by majority of the motorists (69.6\%). Poor rating of VIS on road safety and publicity campaign by motorists had earlier been attested to by the VIOs (table 5) as one of their challenges.

Table 6: Motorists perceptions of VIS

\begin{tabular}{ll}
\hline Variables & Frequency $(\%)$ \\
\hline Contact With VIS & $599(100)$ \\
Yes & - \\
No & \\
Contact Type & $64(10.7)$ \\
Obtain Driver License & $471(78.6)$ \\
Obtain Roadworthiness Certificate & $64(10.7)$ \\
Frequent Vehicle Check for Roadworthiness & \\
Driver's License Acquisition & $421(70.3)$ \\
FRSC & $36(6.0)$ \\
Friends & $78(13.0)$ \\
Driving School & $64(10.7)$ \\
VIS & \\
VIS Thoroughness &
\end{tabular}




\begin{tabular}{lc}
\hline High & $168(28.0)$ \\
Low & $431(72.0)$ \\
VIS Impact & \\
Positive & $394(65.8)$ \\
Negative & $205(34.2)$ \\
Road Safety and Publicity Campaign & \\
Very Good & $94(15.7)$ \\
Good & $103(17.2)$ \\
Poor & $323(53.9)$ \\
Very Poor & $79(13.2)$ \\
VIS Performance & \\
Strongly satisfied & $62(10.4)$ \\
Satisfied & $120(20.0)$ \\
Dissatisfied & $178(29.7)$ \\
Strongly Dissatisfied & $239(39.9)$ \\
\hline
\end{tabular}

Table 7 shows the rating of VIS activities by the motorists. In the rating, yearly issuance of certificate and fee collections was rated high $(98.7 \%)$ despite low rating of thorough vehicle inspection before certification and fee collection (98.8\%).Testing of drivers for driver's license $(98.8 \%)$ was rated low with the same proportion of motorists that rated thoroughness of VIS on vehicle inspection before certification and fee collection. Low rating of VIS on testing of drivers for driver's license by the motorists further affirm VIOs observation of the decrease in the number of motorists (figure 4) that visits VIS for inspection and testing for the purpose of obtaining driver's license. The results also showed high proportional rating of routine road enforcement by the VIS (79.6\%) but rated inadequacy of RW inspection equipment low (98\%). Concerning VIS office environment, $97.7 \%$ of the motorists rated office environment low. Field observation shows that VIS office environment are unkempt at the stations.

Table 7: Rating of VIS activities by motorists

\begin{tabular}{|c|c|c|}
\hline \multirow[t]{2}{*}{ Variables } & High & Low \\
\hline & Freq. (\%) & Freq. $(\%)$ \\
\hline Yearly Issuance of Certificate and Fee Collections & $589(98.7)$ & $10(1.7)$ \\
\hline $\begin{array}{l}\text { Thorough Vehicle Inspection before Certification and Fee } \\
\text { Collection }\end{array}$ & $7(1.2)$ & $592(98.8)$ \\
\hline Testing of Drivers for Drivers' License & $7(1.2)$ & $592(98.8)$ \\
\hline Routine Road Enforcement & $477(79.6)$ & $22(20.4)$ \\
\hline Availability of Equipment & $12(2)$ & $487(98)$ \\
\hline Office Environment Keeping & $14(2.3)$ & $485(97.7)$ \\
\hline Extortions from Motorists & $5(0.8)$ & $494(99.2)$ \\
\hline Charges without Technical Inspection & $427(71.3)$ & $172(28.7)$ \\
\hline Charge Vehicles on Non Collection of Certificate & $599(100)$ & - \\
\hline
\end{tabular}

Although the result of the rating on extortion of the VIS by motoristsin table 7was rated low (99.2\%), nevertheless, charges made bythe VIS without technical inspection and non-collection of roadworthy certificate are highly rated as 
$71.3 \%$ and $100 \%$ respectively. The significance of vehicle condition on any road is immense. Therefore, in the survey, the assessment of the condition of motorists' vehicles was observed.

The condition of motorists' vehicle was assessed based on: tyres - which are either new or used with focus on date of production and expiration, windscreens based on marks on the windscreen, direction indicators, head lamp and brake light - are based on their functionality. Of 599 motorists' vehicles sampled, (526, $87.8 \%$ ) of the vehicles were bought as 'tokunbo' which is vernacular meaning for imported used automobiles and (73, $12.2 \%$ ) are new. Results in table 8 shows that high proportion of the front tyres of the motorists vehicles $(64.7 \%)$ are in good condition but $76.8 \%$ of the rear tyres are in bad condition. Regarding windscreens, the percentage of front windscreen $(88.3 \%)$ and the rear windscreen $(66.6 \%)$ of the motorists' vehicles that is in good condition is high.

Based on direction indicators, the results in table 8 show that both front indicator $(86.8 \%)$ and rear indicator $(79.7 \%)$ of the motorists' vehicles are in good condition. Regarding vehicles headlamp, $99.7 \%$ of the full lamp was working while $50.7 \%$ of the dim lamp was not working. The result further showed that while $44.7 \%$ of the vehicles brake light was working, $55.3 \%$ was not working. From the analyses, it seems the condition of motorists vehicles sampled is more of good condition than being in bad condition. In order to test for the significant difference in the condition of the vehicles sampled, Chi-Square $\left(X^{2}\right)$ test was carried out on the results obtained in table 8 .

Table 8:Percentage and Chi-Square statistics summary of the condition of motorists' vehicles

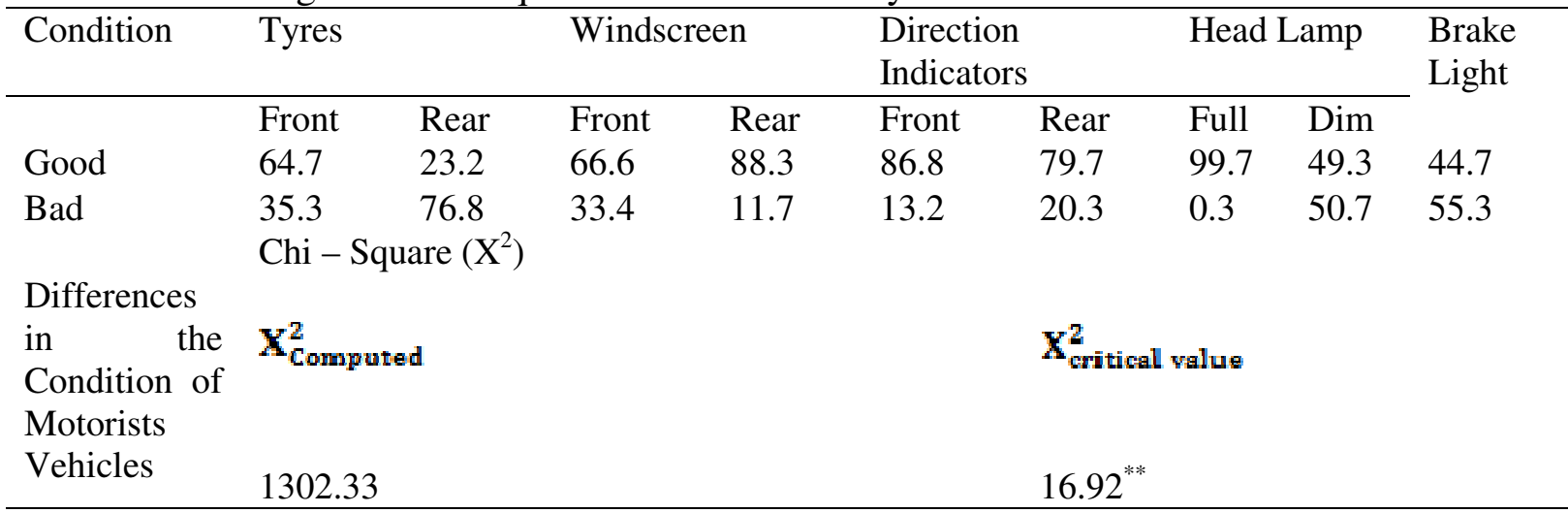

**significant at $5 \%$

The computation in row 5 of table 8 thus shows a significant difference in the observed and expected difference in the good and bad states of motorists' vehicles studied. This is because of variance in the values of $X_{\text {computed }}^{2}=1302.33$ and $X_{\text {eritical value }}^{2}=16.92$ that shows a significant difference at $5 \%$.

\section{Summary and Recommendations}

In this research, vehicle inspection services activities; motorists' perceptions and motorists' vehicles condition were examined in Ijebu Zone of Ogun State. Of the 15,886 vehicles inspected in the zone from January 2014 to August 2015, 73.6\% of the vehicles passed and $26.4 \%$ failed the RW test. 
However, aside Abigi station where $56.8 \%$ vehicles inspected failed RW test, $61.5 \%$ and $78.8 \%$ vehicles inspected in the zone passed RW test in Ijebu - Igbo and Ijebu - Ode stations respectively.

The study showed that there are significant variations in the mean monthly number of vehicles sampled, vehicles that passed and failed the RW test. Nevertheless, the t-statistics showed a significant difference in the mean total number of vehicle that passed $(\bar{x}=1104.7500)$ and failed $(\bar{x}=287.3750) \mathrm{RW}$ test in the zone. The number of motorists that visit VIS for driving test as revealed by the study was rated low (98.8\%) and the implication is that most of the motorists in the zone may not be exposed to some technicalities required that can help in managing mishaps. Man was perceived to have accounted for $83.4 \%$ of the causes of road accidents in the zone and man's actions that often results to the mishaps include over speeding, drunk driving, inexperience, use of phone on wheel, neglect of vehicles mechanical faults and so on.

Revenue generation capability of VIS in the zone from the study seems to be more important to the state government. Thus, the state government is perceived to be interested in the revenue generating capability of the VIS with little focus on staff remunerations, staff training, provision of equipment and patrol vehicles for the VIOs. The results which is in line with (Otuyemi, 2006; Alade, 2012; Filibus, 2012) studies but invariant with Daniel (2015) alleged VIOs extortions by the public. Of the 599 motorists' vehicles sampled, $87.8 \%$ are imported but used automobiles and $12.2 \%$ are bought new. Nevertheless, the conditions of the vehicles based on the study assessment are more of good condition than being in bad condition.

In spite of the challenges faced by the VIOs and dissatisfaction on their performance by the motorists, VIS believes to generate positive impact and most of the officers (VIOs) are satisfied with the job. Hence, there is the need to: (i) encourage intended motorists to visit VIS stations for driving test, (ii) encourage motorists to visit VIS stations for routine RW test, (iii) provide periodic safety and roadworthiness enlightenment to motorists (iv) equip VIS stations with state of the art equipment and patrol vehicles, (v) organize regular seminar and training for staff and (v) maintain periodic staff remunerations review. Provision of periodic safety and roadworthiness enlightenment to exiting and would be motorists will assist motorists to understand the importance of routine inspection of their vehicles for RW test and equipping and periodic review of staff remunerations will enable VIOs to function successfully in sustaining safety of life and properties on the highways.

\section{References}

Alade, W.R. (2012). The Roles of Vehicle Inspection Officers in Authenticating Motor Vehicle Road Worthiness Certification Presented at the National Conference on Vehicle Road Worthiness Inspection and Testing Organized By National Automotive Council at Sheraton Hotel and Towers, Abuja on 3rd and 4th July, 2012

Arosanyin, G.T. (2002). Baseline Estimates of Environment cost of Nigerian Transport System in Jimoh, H.I. and Ifabiyi, I.P. (Eds). 
Contemporary Issues in Environmental Studies.

Badejo, B.A. (2012). "Strategies towards Improving Urban Mobility and Road Safety in Nigeria: The Lagos State Intervention Examples." Being a paper presented at the $12^{\text {th }}$ PRI World Congress held at Marrakech Morocco. $6^{\text {th }}-9^{\text {th }}$ June 2012.

Badejo, B.A. (2014a). Road Safety and Nigerian Development: The Emergency Now. Paper presented at $3^{\text {rd }}$ Kadiri Annual Lecture, Centre for Environmental Studies and Design held at Moshood Abiola Polytechnic on $18^{\text {th }}$ March 2014.

Badejo, B.A. (2014b). Transporting the Future Today: Portrait of Nigeria $65^{\text {th }}$ Inaugural Lecture. Olabisi Onabanjo University, Ago-Iwoye, Ogun state. Held in $11^{\text {th }}$ February 2014.

Dabiri, T.A. (2006). The Use of Telecommunications in Accident Causation and Reduction: A Case Study of Lagos Metropolis. An M.Sc Dissertation Submitted to the Department of Geography, School of Postgraduate Studies, University of Lagos, Akoka.

Daniel, A. (2015). El-Rufai Dissolves State VIO, Sacked All Officers.

http://www.informationng.com. December, 8 2015, accessed January 2016.

EUROPA (2003). Activities of the European Union Summaries of Legislation. Road Safety Action Programme. Mc Gram-Hall book United State.

European Transport Safety Council, (1999). Police Enforcement Strategies to Reduce Traffic Casualties in Europe. European Transport Safety Council, Brussels.
European Transport Safety Council (ETSC), (2013). Back on track to reach the EU 2020Road Safety Target? In: Seventh Road Safety PIN Report. European Transport Safety Council (ETSC).

Filibus, B.E. (2012). The Roles of VIOs in Authentic Motor Vehicle Roadworthiness Certification Enforcement Traffic Monitoring Unit Directorate of Road Traffic Services, FCT presented at The National Conference on Vehicle Roadworthiness Inspection and Testing organized by National Automotive Council at Sheraton Hotel and Towers, Abuja on 3rd and 4th July, 2012.

Lagos State Government 2013.Vehicle Inspection Service (VIS) Campaign Week 2012-2013. Ministry of Transportation.

Lagos State Ministry of Transportation (2015). Report on Ojuelegba Truck Accident submitted to the Office of the Governor, Alausa Secretariat Ikeja.

Okoko, E. and Arosanyin, G.T. (2004). "An analysis of the trend of road accidents in Nigeria" International Journal of Transport Sties, 1(2):1-13.

Olokesusi, F. and Asiyanbola, R.A. (1997). "Transport and the Nigeria Environment: An overview of the Challenges and Policy Implications" Ife Social Sciences Review, 14(1\&2): 1-15.

Onakomaiya, S.O. (1991a). General Trend of Safety Road Accident Records in Nigeria: In Bolade Tunji and Ogunsanya. A.A. (Eds): Accident control and Safety Measure in Mass Transit Operations in Nigeria. Ibadan University Press. 
Onakomaiya, S.O. (1991b). "Deaths on Our Road: Who is to Blame?" A paper presented at Ogun State University, Ago-Iwoye, Nigeria.

Otuyemi, V.A. (2006). An Evaluation of Activities of Road Traffic Officers (VIOs) in Road Transport Management in Ogun State, Nigeria. A Dissertation submitted to the Postgraduate School in partial fulfillment of the requirements for the award of Postgraduate Diploma in Transport Studies, Centre for Transport Studies Olabisi Onabanjo University Ago-Iwoye Ogun State Nigeria.

Owen, W. (1968). Distance and Development, Brookings Institutions, Washington D.C.

Raji, B.A. (1998). The Use of Telecommunication Systems as Alternative Approach to Accidents Reduction in Republic of Togo. A Case Study of Lome. A project submitted to the Department of Geography and Regional Planning Ogun State University, Ago Iwoye.

Raji, B.A. (2014). Automobile Safety Belts Usage in Ibadan Metropolis, AgoIwoye. Journal of Social and Behavioural Sciences, 3(1): 36-54.

Raji, B.A., Oloriegbe, A.D. and Adeoshun, A.A. (2014). Road Users' Awareness of and Compliance with Pedestrian Crossings in Ikeja Lagos, Nigeria A paper presented at the 3rd International Conference of Urban and Regional Planning (ICURP14), Urban Agenda: Realities Challenges and Potentials organised by the Department of Urban and Regional Planning, University of Lagos, Nigeria between 13th-15th October.

Raji, B.A. and Solanke, M.O. (2009). Flow Pattern of Vehicular Traffic along Highway Toll Plaza in Ogun State. Indonesia Journal of Geography, 41(1): 53-70.

Raji, B.A. and Solanke, M.O. (2013). Comparative Analysis of School Children Exposure to Road Traffic Accidents in Ijebu North Local Government Area of Ogun State, Nigeria. Journal of Engineering and Environmental Studies, 4(2): 1-12

Reindhard, K. (2005). Sustainable Transport: A Sourcebook for Policy Makers in Developing Cities Module 4b. Inspection, Maintenance and Roadworthiness. Federal Ministry for Economic Cooperation and Development. Germany.

Varhelyi, A. (1998). Drivers' Speed Behaviour at a Zebra Crossing: A Case Study. Accident Annual Prev. 30(6): 731-743. 